\title{
Response of Groundnut Genotypes to Leaf Miner (Aproaerema modicella Deventer) Under Field Screening
}

\author{
P. Arunachalam ${ }^{1}$, Zadda Kavitha ${ }^{2}$ \\ ${ }^{1,2}$ Dryland Agricultural Research Station, Tamil Nadu Agricultural University, \\ Chettinad - 630 102, Tamil Nadu, India
}

\begin{abstract}
Twenty five groundnut genotypes were field screened for leaf miner and defoliator incidence. The study was conducted at Dryland Agricultural Research Station, Chettinad during Kharif 201 land Rabi 2011-12. Periodic observations on leaf miner and defoliator damage were recorded in all the genotypes. Incidence of leaf miner was increased with raise in maximum temperature and decrease in relative humidity, rainfall and leaf wetness. The field screening results revealed that less leaf miner incidence was recorded in the genotypes viz., ICGV 06424, ICGV 07220, ICGV 07222, ICGV 07240, ICGV 07245, ICGV 07247, ICGV 07268, ICGS 11 and $V R I(G n) 6$ in both the seasons. To identify the resistant genotypes to leaf miner, further screening studies under in vitro conditions with the identified genotypes with less incidence of leaf miner are required.
\end{abstract}

Keywords: Peanut, leaf miner, defoliator, Field screening, Arachis hypogaea

\section{INTRODUCTION}

Groundnut (Arachis hypogaea L.) is an important oilseed crop of tropical and subtropical regions of the world. In India, groundnut occupies an area of 6.9 million ha. About $80 \%$ of the peanut area in the country is rain dependent and the productivity is very low compared to irrigated peanut. In India, 70\% of the groundnut area and $75 \%$ of the production are concentrated in the four states viz., Gujarat, Andhra Pradesh, Tamil Nadu and Karnataka.

The groundnut leaf miner, Aproaerema modicella Deventer (Gelechiidae: Lepidoptera) is an oligophagous insect pest feeding on leguminous host plants and a serious insect pest of groundnut in rainy and post rainy seasons in India. This insect is considered as the most important pest in India, particularly in rainfed situation (Reddy, 1988; Praveena et.al., 2011). More than 50\% pod yield loss due to leaf miner was reported from Tamil Nadu, India (Logiswaran and Mohanasundaram, 1985).

As more than $70 \%$ of groundnut growing area comes under rainfed cultivation, resource poor farmers are neither adopting nor affordable to take any plant protection measures. In this context, identifying suitable high yielding groundnut genotypes less prone to insect pests will be a boon for the rainfed farmers. Hence, this study was undertaken to evaluate diverse groundnut genotypes for their resistance/tolerance to groundnut leaf miner and defoliators.

\section{MATERIALS AND METHODS}

A total for 25 genotypes were screened under field conditions at Dryland Agricultural Research Station (DARS), Chettinad. The genotypes received from International Crop Research Institute for the Semi-Arid Tropics (ICRISAT), Patancheru were ICGV 06423, ICGV 06424, ICGV 07219, ICGV 07220, ICGV 07222, ICGV 07228, ICGV 07240, ICGV 07241, ICGV 07245, ICGV 07247, ICGV 07262, ICGV 07268, ICG 4544, ICGS 11 and Chico. ICGV 91114, Narayani, JL 24, TPT 25, TCGS 913 and K 134 were received from Regional Agricultural Research Station, Tirupati. The varieties, TMV 7, TMV (Gn) 13, VRI (Gn) 6 and VRI (Gn) 7 released from Tamil Nadu Agricultural University were also included in this study. Each genotype was sown in 5 rows of $4 \mathrm{~m}$ length with the spacing of $30 \times 15 \mathrm{~cm}$ in a replicated design. The crop was grown by adopting recommended package of practices except for the plant protection measures.

The crop was raised in two seasons i.e., Kharif (August to November 2011) and Rabi-Summer (December 2011 to April 2012). Observations on leaf miner incidence and defoliator damage were recorded regularly at 15 days interval. Observations were made on top five leaves of five randomly selected plants in each replication for number of leaflets damaged by leaf miner and extent of defoliation by defoliators. From these observations, per cent incidence of leaf miner and per cent defoliation were calculated. As the variety, TMV 7 is predominantly grown in this region, the insect pest incidence on this variety in both the seasons was correlated with the weather parameters (maximum temperature, minimum temperature, relative humidity and rainfall) to assess the favourable environmental factors to the groundnut leaf miner. The weather parameters were accessed from the Automatic Weather Station, located at Dryland Agricultural Research Station, Chettinad. 


\section{RESULTS AND DISCUSSION}

3.1. Influence of Weather Parameters on Leaf Miner Incidence:

The leaf miner incidence on groundnut variety TMV 7 for Kharif and Rabi seasons and its relationship with the weather factors are presented in Figure 1 and 2. In Kharif, leaf miner incidence has started from $3^{\text {rd }}$ week of sowing and attained its peak (26.1\%) at 45 days after sowing (DAS). Then the incidence declined steeply and reduced to $3.8 \%$ at 60 DAS. After this period, no significant damage was noticed. A change in this trend was observed in Rabi wherein, the incidence has started at 30 DAS, attained its peak (20.8\%) at 60 DAS. Then it declined to $5.1 \%$ at 75 DAS and $1.5 \%$ at 90 DAS.

Based on these observations, leaf miner incidence in groundnut appears to be non dependent on crop stage but influenced mainly by the prevailing weather factors. During Kharif, maximum incidence of leaf miner coincided with the increase in maximum temperature and decrease in relative humidity, rainfall and leaf wetness. Similar trend was observed during the Rabi season also. In general, minimum temperature had negligible influence on the insect incidence. These findings are in line with Lewin et al. (1979) who reported positive correlation of temperature and negative correlation of rainfall with leaf miner incidence. In contrast, Logiswaran and Mohanasundaram (1986) reported a significant negative correlation between maximum and minimum temperatures and groundnut leaf miner (GLM) infestation levels and no correlation with rainfall.
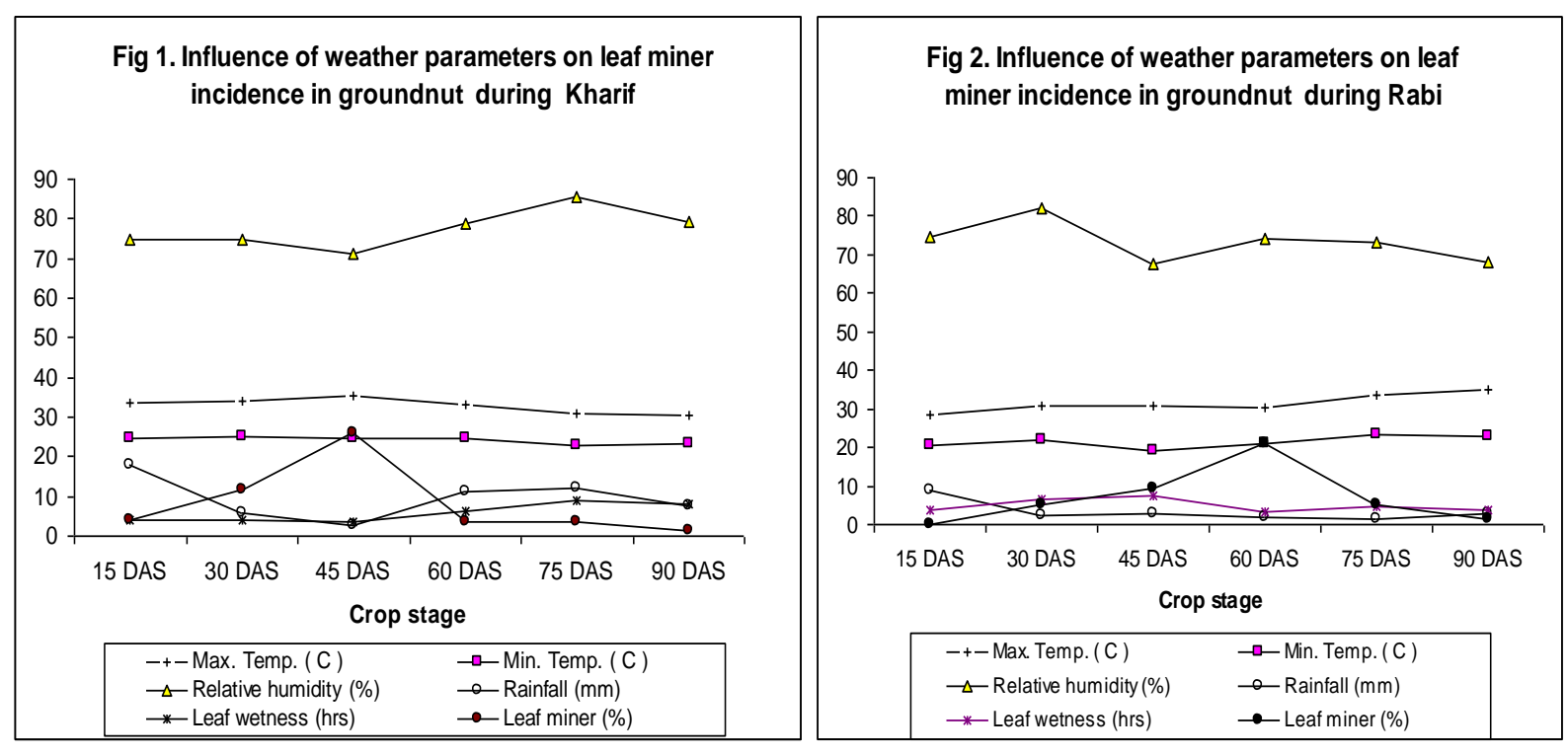

3.2. Response of groundnut genotypes to leaf miner during Kharif and Rabi seasons

3.2.1. Kharif: Among the various accessions evaluated, maximum leaf miner incidence was observed in Chico (20.5\%), TPT 25 (17\%), TMV 7 (26.1\%), K 134 (8.5\%) and TCGS 913 (3\%) at 15, 30, 45, 60 and 75 days after sowing (DAS) respectively (Table 1). The mean percentage of incidence was high (10.6\%) at 45 DAS. Genotypes observed with more leaf miner incidence at 45 DAS were TMV 7 (26.1\%), ICG 4544 (14\%), ICGV 06423 (13.5\%), K 134 (13\%), ICGV 07219, ICGV 07262 and TMV(Gn) 13 (11.5\%), ICGV 07241 (11\%), Narayani (10.5\%), JL 24, ICGV 07240, ICGV 07220 and ICGV 07247 (10\%). The mean per cent incidence at 60 DAS was $4.2 \%$ and gradually decreased to $0.6 \%$ at 75 DAS. Senguttuvan and Sujatha (2000) reported that the genotypes, ICGV 87141, ICGV 87453, ICG 2271, VGN 13 and VGN 52 were less susceptible to groundnut leafminer. Satyanarayana Rao (2002) reported the susceptibility of groundnut variety, ICG 221 to leaf miner and more attractiveness of ICG 5040 for egg laying of leaf miner. Praveena et.al. (2011a) reported that genotypes, Dh-4-3, ICGS-11, R-9227, R-8808 and R-9214 were moderately resistant with 25 to 35 per cent foliage damage and higher pod yield under field screening of groundnut varieties against leaf miner.

3.2.2. Rabi: There was no significant observable leaf miner damage among the genotypes up to 45 DAS. Observations taken at 60 DAS revealed a significant build up of leaf miner damage. The minimum incidence was noticed in ICGV 07247 (0.5\%) and maximum incidence was noticed in TMV (Gn) 13 (36.5\%) at 60 DAS. The genotypes that recorded 10 to $20 \%$ incidence were ICGV 06423, ICGV 07228, ICG 4544, JL 24, TPT 25, K 134, Chico and VRI (Gn) 7. The accessions recorded 21 to 31.5 per cent incidence was ICGV 07241, ICGV 91114, Narayani, TMV 7 and TCGS 913. At 75 DAS, the incidence was very low with a mean incidence of $0.4 \%$. 
Response Of Groundnut Genotypes To Leaf Miner (Aproaerema Modicella Deventer) Under Field

Table 1. Per cent Incidence Of Leaf Miner In Different Groundnut Genotypes

\begin{tabular}{|c|c|c|c|c|c|c|c|}
\hline \multirow{2}{*}{ Genotype } & \multicolumn{4}{|c|}{ Kharif Season } & \multicolumn{3}{|c|}{ Rabi Season } \\
\hline & 15 DAS & 30 DAS & 45 DAS & 60 DAS & 45 DAS & 60 DAS & 75 DAS \\
\hline ICGV 06423 & 14.0 & 10.5 & 13.5 & 6.0 & 0.5 & 13.0 & 0.5 \\
\hline ICGV 06424 & 7.0 & 4.0 & 9.0 & 5.5 & 0.5 & 5.5 & 0.5 \\
\hline ICGV 07219 & 11.5 & 5.0 & 11.5 & 1.5 & 0.0 & 5.0 & 2.5 \\
\hline ICGV 07220 & 7.0 & 4.0 & 10.0 & 2.0 & 0.0 & 4.0 & 0.0 \\
\hline ICGV 07222 & 7.0 & 8.5 & 6.0 & 4.0 & 0.0 & 4.5 & 0.0 \\
\hline ICGV 07228 & 6.0 & 11.0 & 8.5 & 3.5 & 0.0 & 13.5 & 0.0 \\
\hline ICGV 07240 & 4.0 & 3.0 & 10.0 & 1.5 & 0.0 & 3.5 & 0.0 \\
\hline ICGV 07241 & 11.5 & 5.0 & 11.0 & 1.5 & 0.5 & 26.0 & 0.0 \\
\hline ICGV 07245 & 6.0 & 7.0 & 9.0 & 0.5 & 0.0 & 5.0 & 0.0 \\
\hline ICGV 07247 & 7.0 & 2.5 & 10.0 & 0.5 & 0.0 & 0.5 & 0.0 \\
\hline ICGV 07262 & 5.0 & 1.5 & 11.5 & 2.5 & 0.0 & 3.0 & 0.0 \\
\hline ICGV 07268 & 4.5 & 8.0 & 8.0 & 7.0 & 0.0 & 7.5 & 0.0 \\
\hline ICGV 91114 & 10.0 & 8.5 & 8.0 & 6.0 & 0.5 & 24.0 & 0.0 \\
\hline ICG 4544 & 10.5 & 8.5 & 14.0 & 4.5 & 0.5 & 13.0 & 0.0 \\
\hline ICGS 11 & 0.0 & 7.0 & 8.0 & 3.0 & 0.0 & 2.5 & 0.0 \\
\hline Narayani & 6.0 & 10.0 & 10.5 & 6.0 & 1.0 & 25.5 & 0.0 \\
\hline JL 24 & 15.5 & 10.0 & 10.0 & 7.5 & 1.0 & 20.0 & 1.5 \\
\hline ТРT 25 & 11.5 & 17.0 & 9.0 & 7.5 & 2.0 & 11.0 & 0.0 \\
\hline TCGS 913 & 6.5 & 16.0 & 9.5 & 7.0 & 3.0 & 31.5 & 0.0 \\
\hline K 134 & 9.0 & 4.5 & 13.0 & 8.5 & 0.5 & 18.0 & 0.0 \\
\hline Chico & 20.5 & 9.0 & 9.5 & 4.5 & 0.0 & 10.0 & 0.0 \\
\hline VRI (Gn) 6 & 2.5 & 3.0 & 8.5 & 2.5 & 0.0 & 6.5 & 0.0 \\
\hline VRI (Gn) 7 & 3.0 & 1.5 & 9.0 & 1.5 & 0.0 & 12.0 & 0.0 \\
\hline TMV 7 & 4.2 & 11.0 & 26.1 & 3.8 & 3.6 & 20.8 & 5.1 \\
\hline TMV (Gn) 13 & 4.5 & 1.5 & 11.5 & 7.5 & 2.0 & 36.5 & 1.0 \\
\hline Mean & 7.7 & 7.1 & 10.6 & 4.2 & 0.6 & 12.9 & 0.4 \\
\hline S.Em. \pm & 0.92 & 0.85 & 0.74 & 0.50 & 0.16 & 1.99 & 0.12 \\
\hline C.D. at $5 \%$ & 0.60 & 0.61 & 0.35 & 0.67 & 1.63 & 0.77 & 2.49 \\
\hline
\end{tabular}

\subsection{Defoliators response}

The major defoliator observed in groundnut ecosystem was Spodoptera litura but in low numbers. In Kharif, the mean defoliation of $0.57 \%, 0.71 \%, 1.31 \%$ and $1.04 \%$ was recorded at 45, 60, 75 and 90 DAS respectively. Maximum defoliation of 4.94\% (TPT 25), 1.88\% (ICGV 07220), $7.50 \%$ (Chico) and $1.50 \%$ (ICGV 07262 and Chico) at 45, 60, 75 and 90 days after sowing was recorded respectively (Table 2).

In Rabi season, the mean defoliation of $0.89 \%$ and $0.66 \%$ was observed at 60 and 90 DAS respectively. During the cropping period, maximum defoliation was noticed in ICGV $91114(2.56 \%)$ at 90 DAS followed by TCGS $913(2.38 \%)$ at 60 DAS. However, defoliator damage was not up to the level to cause any economic damage either in the varieties or in the groundnut genotypes.

\section{CONCLUSION}

The present study revealed that among the leaf feeders, the leaf miner damage was found to be affecting the groundnut crop. The leaf miner incidence was maximum at 45 DAS in rainy season and 60 DAS in post rainy season. Leaf miner incidence was increased with raise in maximum temperature and decrease in relative humidity, rainfall and leaf wetness. The field screening result revealed the less than or equal to 10 per cent leaf miner incidence was recorded in the genotypes viz., ICGV 06424, ICGV 07220, ICGV 07222, ICGV 07240, ICGV 07245, ICGV 07247, ICGV 07268, ICGS 11 and VRI (Gn) 6 in both the seasons. Hence, these genotypes have shown tolerance to the leaf miner infestation irrespective of the seasons. No economic damage was noticed in genotypes due to defoliators. Further screening studies under laboratory conditions on genotypes with less incidence of leaf miner are required to identify the resistant genotypes. 
Response Of Groundnut Genotypes To Leaf Miner (Aproaerema Modicella Deventer) Under Field

TABLE 2. PER CENT DEFOLIATION IN DIFFERENT GROUNDNUT GENOTYPES

\begin{tabular}{|c|c|c|c|c|c|c|}
\hline \multirow{2}{*}{ Genotype } & \multicolumn{4}{|c|}{ Kharif Season } & \multicolumn{2}{|c|}{ Rabi Season } \\
\hline & 45 DAS & 60 DAS & 75 DAS & 90 DAS & 60 DAS & 90 DAS \\
\hline ICGV 06423 & 0.00 & 0.98 & 0.66 & 1.00 & 1.22 & 0.00 \\
\hline ICGV 06424 & 0.06 & 1.16 & 0.12 & 1.00 & 0.34 & 0.10 \\
\hline ICGV 07219 & 0.08 & 0.94 & 0.36 & 1.00 & 1.50 & 0.00 \\
\hline ICGV 07220 & 0.00 & 1.88 & 0.80 & 1.00 & 0.10 & 0.40 \\
\hline ICGV 07222 & 1.42 & 0.86 & 0.10 & 1.00 & 0.42 & 0.32 \\
\hline ICGV 07228 & 0.08 & 0.38 & 0.42 & 1.00 & 0.70 & 0.00 \\
\hline ICGV 07240 & 0.04 & 0.32 & 0.12 & 1.00 & 0.42 & 0.98 \\
\hline ICGV 07241 & 0.16 & 0.30 & 1.28 & 1.00 & 1.52 & 0.86 \\
\hline ICGV 07245 & 0.16 & 1.02 & 0.38 & 1.00 & 0.50 & 0.00 \\
\hline ICGV 07247 & 0.34 & 0.14 & 0.62 & 1.00 & 0.36 & 0.06 \\
\hline ICGV 07262 & 0.00 & 0.10 & 5.26 & 1.50 & 0.36 & 0.68 \\
\hline ICGV 07268 & 0.04 & 0.00 & 1.52 & 1.00 & 0.28 & 0.74 \\
\hline ICGV 91114 & 0.78 & 0.58 & 1.36 & 1.00 & 1.50 & 2.56 \\
\hline ICG 4544 & 0.56 & 0.26 & 0.66 & 1.00 & 1.00 & 1.68 \\
\hline ICGS 11 & 0.16 & 0.18 & 0.34 & 1.00 & 0.56 & 0.14 \\
\hline Narayani & 1.90 & 0.96 & 1.16 & 1.00 & 0.96 & 2.00 \\
\hline JL 24 & 0.42 & 1.38 & 1.38 & 1.00 & 1.70 & 0.60 \\
\hline ТPТ 25 & 4.94 & 1.36 & 0.68 & 1.00 & 1.18 & 0.26 \\
\hline TCGS 913 & 0.73 & 1.48 & 0.08 & 1.00 & 2.38 & 0.26 \\
\hline K 134 & 0.12 & 0.42 & 1.02 & 1.00 & 0.54 & 1.78 \\
\hline Chico & 0.14 & 1.30 & 7.50 & 1.50 & 1.10 & 1.06 \\
\hline VRI (Gn) 6 & 1.20 & 0.52 & 1.30 & 1.00 & 0.20 & 0.24 \\
\hline VRI (Gn) 7 & 0.03 & 0.00 & 0.90 & 1.00 & 0.94 & 0.24 \\
\hline TMV 7 & 0.14 & 0.98 & 2.34 & 1.00 & 1.38 & 0.50 \\
\hline TMV (Gn) 13 & 0.68 & 0.28 & 2.46 & 1.00 & 1.20 & 1.16 \\
\hline Mean & 0.57 & 0.71 & 1.31 & 1.04 & 0.89 & 0.66 \\
\hline S.Em. \pm & 0.21 & 0.11 & 0.15 & 0.13 & 0.57 & 0.70 \\
\hline C.D. at $5 \%$ & 1.40 & 0.74 & 0.52 & 0.13 & 0.63 & 1.05 \\
\hline
\end{tabular}

\section{Acknowledgment}

The authors gratefully acknowledges Dr.S.N.Nigam, Principal Scientist (Groundnut), ICRISAT, Patancheru; Dr. R.P.Vasanthi, Principal Scientist, Dr.T.Muralikrishna, Senior Scientist, Regional Agricultural Research Station, Thirupathi for providing groundnut breeding lines used in this study

[1] Reddy, The Groundnut, ICAR Publication, 1988, pp. 572.

\section{References}

[2] Y.V. Praveena, K. Kotikal, J.S. Awaknavar, P.V. Kenchangoudar, and Somashekar. Evaluation of newer insecticides against groundnut leaf miner Aproaerema modicella Deventer Karnataka J. Agric. Sci., 24 (4), 2011, 542-545

[3] G. Logiswaran, and M. Mohanasundaram, Effect of intercropping, spacing and mulching in the control of groundnut leaf miner, Aproaerema modicella Deventer (Gelechiidae: Lepidoptera). Madras Agricultural Journal, 72, 1985, 695-700.

[4] H.D. Lewin, R.S. Saroja, D. Sundararaju, and M.D. Padmanabhan, Influence of sowing time and weather on the incidence of leaf miner. Indian Journal of Agricultural Sciences. 49, 1979, 886-891.

[5] G. Logiswaran, and M. Mohanasundaram, Influence of weather factors on the catches of moths of groundnut leaf miner Aproaerema modicella Deventer in the light trap. Entomon, 12, 1986, 147-150.

[6] T. Senguttuvan, and K. Sujatha, Biochemical basis of resistance in groundnut against leaf miner. International Arachis Newsletter, 20, 2000, 69-71.

[7] R.V. Satyanarayana Rao, Method of Screening for Resistance to Leafminer, Aproaerema modicella (Deventer) Under Greenhouse Conditions. Annals of Plant Protection Sciences. 10 (1), 2002, 38-41.

[8] Y.V. Praveena, K. Kotikal, J.S. Awaknavar, P.V. Kenchangoudar, and Somashekar, Screening of groundnut varieties against leaf miner Aproaerema modicella Deventer Karnataka J. Agric. Sci., 24 (4), 2011a. 561-56. 